\title{
Tarkastelussa kasvatuksen ja koulutuksen sosiaalinen oikeudenmukaisuus ja tasa-arvo
}

\begin{abstract}
11
Muun muassa syrjäytymisvaarassa oleviin liittyvää tutkimusta vahvistetaan kasvatustieteissä. Helsingin yliopiston kasvatuksen ja koulutuksen sosiaalisen oikeudenmukaisuuden ja tasa-arvon professuuri on Suomessa ensimmäinen laatuaan.
\end{abstract}

HELSINGIN YLIOPISTON käyttäytymistieteellisessä tiedekunnassa alettiin suunnitella kasvatuksen ja koulutuksen sosiaalisen oikeudenmukaisuuden ja tasa-arvon tenure-professuuria ${ }^{1}$ muutama vuosi sitten. Suunnitteluun osallistuivat muun muassa tiedekunnan dekaani, laitoksen johtaja ja joitakin professoreja. Teema nähtiin tärkeäksi eikä ehkä vähiten sen takia, että näihin aiheisiin liittyvä tutkimus oli jo tiedekunnassa vahvaa. Professuuria haki lähes 20 henkilöä Suomesta ja maailmalta. Usean arviointivaiheen ja puolentoista vuoden prosessin jälkeen tulin ilokseni valituksi tehtävään, joka alkoi vuoden 2014 alussa.

Tässä näkökulmassa tarkastelen praktisesta ja kokemukseeni perustavasta positiosta kasvatuksen ja koulutuksen sosiaalista oikeudenmukaisuutta ja tasa-arvoa sekä kerron suunnitelmistani professuuriin liittyen.
Olen kollegoideni kanssa tehnyt avauksia sosiaaliseen oikeudenmukaisuuteen ja tasa-arvoon kasvatus- ja aikuiskasvatustieteeseen, koulutuspolitiikkaan, koulutussosiologiaan, feministiseen tutkimukseen, työelämän tutkimukseen, nuorisotutkimukseen ja kriminologiaan (esim. Ikävalko \& Brunila 2011, Brunila \& Isopahkala-Bouret, painossa, Brunila, Hakala, Lahelma \& Teittinen 2013). Professuuriin valituksi tuleminen sai aikaan muutamia unettomia öitä innostuksen takia, sillä voisin lyhyissä vuosikymmenen kestäneissä pätkäprojekteissa toimimisen jälkeen hyödyntää kokemustamme laajemmin ja systemaattisemmin.

Professuuri on merkittävä sekä kansallisesti että kansainvälisesti. Se mahdollistaa aiemman tutkimuksen, opetuksen ja yhteiskunnallisen vaikuttamisen jatkuvuuden ja uudet avaukset ja yhteistyön tavat. Professuuri on jo herättänyt poliittisten pätöksente- 
kijöiden, median, koulutusorganisaatioiden, tutkijoiden ja muiden asiantuntijoiden kiinnostuksen. Olen saanut kutsuja tulla kertomaan lähitulevaisuuden suunnitelmista muun muassa ministeriöistä, Opetushallituksesta ja tasa-arvoasiain neuvottelukunnalta.

Tenure-professuurin voisi ajatella individualistisena oman imperiumin rakentamisena, mihin jossain mielessä nykyinen yliopistojen arviointijärjestelmäkin perustaa. Olemassaolon oikeutus lunastetaan kansainvälisin julkaisuin, ulkopuolelta hankituin tutkimusrahoituksin, tutkimusryhmää johtamalla ja opetusta kehittämällä. Näen professuurin kuitenkin hieman toisin. Haluan olla mukana vahvistamassa kollektiivisuutta, kriittistä ajattelua, demokraattisuutta ja tiedon muotoutumista yhteisöllisesti. Professuuri ei ole resurssi pelkästään oikeudenmukaisuuden ja tasa-arvon tutkimukselle vaan myös laajemmin yhteiskuntatieteellisen kasvatustieteen tulevaisuudelle.

Helsingin yliopisto ja käyttäytymistieteiden laitos osoittivat tarkkanäköisyyttä professuurin teeman ja ajankohdan osalta. Mikä voisi olla parempi ajankohta, kuin nykyinen yhteiskunnallinen tilanne, jossa koulutus markkinoituu, tietokapitalismi säätelee tietoa, koko koulutusjärjestelmän nähdään olevan jonkinlaisessa kriisissä ja me tutkijat lunastamme olemassaolomme oikeutta myyntineuvottelevina tulosyksikköinä?

Ajalle tyypillinen eetos pyrkii helpommin, sujuvammin ja tehokkaammin hallittavuuteen myös yliopistossa (Vainio 2012). Mutta onneksi on muutakin. Olen seurannut jo jonkin aikaa kriittisen ajattelun uudelleen vahvistumista yliopistolla. Opiskelijat hakeutuvat mielellään kriittistä ajattelua vaaliville kursseille, joissa tarkastellaan esimerkiksi kasvatuksen ja koulutuksen eriarvoisuutta ja mahdollisuuksia vaikuttaa siihen. Poliittiset päätöksentekijät ovat kiinnostuneita tasa-arvon ja eriarvoisuuden kysymyksistä ja koulutusjärjestelmään on alettu kohdistaa odotuksia, kuten tasapuolisuutta, yleissivistystä ja kriittistä ajattelua.

Koulu vaikuttaa olevan alati vilkkaan keskustelun kohteena. Opettajankoulutusta on kehitetty vuosikymmenten ajan tuomalla siihen vahvemmin vallan, eriarvoisuuden ja tasa-arvon kysymyksiä ja purkamalla ajatusta opettajasta itseriittoisena kansankynttilänä (esim. Lehtonen 2011, Ikävalko 2010). Mutta mistä kertoo teknologinen determinismi, joka sinnikkäästi nousee pintaan yhä uudelleen? On ihan hyväksyttävää, että tekniikkaa hyödynnetään koulutuksessa, mutta teknologiapolitiikkaan tarvitaan laajempaa kriittistä keskustelua, ja siihen liittyy myös monenlaista globaalia eriarvoisuutta ja riistoa (de Andreotti Oliveira \& Pashby 2013, Paakkari, tulossa). Keitä tai mitä teknologia lopulta hyödyttää? En ymmärrä, minkä takia me kasvatuksen ja koulutuksen asiantuntijat tyydymme niin usein seuraamaan vierestä, kun muut tahot yritysjohtajista konsultteihin haluavat valjastaa koulutusta milloin minkäkin intressin palvelemiseen?

Miten saisimme myös aikuiskasvatuksen ja aikuiskoulutuksen vilkkaamman keskustelun kohteeksi? Aikuiskoulutusta jo usean vuoden ajan tutkineena ja siitä kriittisestikin eri foorumeilla kirjoittaneena ja puhuneena toivoisin laaja-alaisempaa keskustelua aikuiskoulutuksen tavoitteista ja toimintatavoista siinä yhteiskunnallisessa tilanteessa, jossa elämme.

\section{TUTKIMUKSELLISIA AVAUKSIA}

Olen tutkimusryhmäni kanssa seurannut jo jonkin aikaa koulutuspolitiikassa ja koulutuksen käytännöissä tapahtuvia muutoksia Suomessa ja kansainvälisesti. Olemme usein löytäneet itsemme tutkimasta yhteiskunnallisia valtasuhteita niin sanotusti marginaalista käsin, kuten esimerkiksi tarkastelemalla sitä koulutusta, jota tarjotaan koulutusjärjestelmän ja työelämän ulkopuolella eläville nuorille aikuisille, vammaisille ja maahanmuuttajille. Kyse on koulutuksesta, joka luokitellaan aikuiskoulutukseksi tai ammatilliseksi koulutukseksi. Osa näistä nuorista on elänyt tai elää parhaillaan vankilassa. Olemme vierailleet useissa koulutusorganisaatioissa ja -ohjelmissa ja osallistuneet joidenkin ohjelmien opetukseen. Vierailujen aikana olemme keskustelleet sekä nuorten että heidän kanssaan työskentelevien kanssa. Nämä lähemmäs sadan henkilön kanssa käydyt keskustelut edustavat varsin erilaista todellisuutta kuin se julkinen aikuisilta aikuisille suuntautunut huolipuhe, joka sekä patologisoi nuoria että saa heidät näyttämään kykenemättömiltä päättämään omista asioistaan tai toimimaan aktiivisina yhteiskunnan kansalaisina. Nuorille tarjottava lyhytkestoinen ja lähinnä projekteina toteutetta- 
va koulutus ei näytä kykenevän antamaan heille välineitä omaan elämään ja yhteiskuntaan vaikuttamisessa (myös Niemi \& Kurki 2013, Kurki \& Brunila, tulossa). Passiivisiin tai oppimishaluttomiin nuoriin emme ole törmänneet. Sen sijaan olemme tutustuneet nuoriin, jotka kokevat, että huolipuhe ei tavoita tai auta heitä (esim. Mertanen 2013, Brunila 2012).

Mitä tekevät nuorten kanssa työskentelevät? He ovat työhönsä sitoutuneita, mutta joutuvat jatkuvasti hakemaan lyhytkestoista projektirahoitusta, koska muita resursseja ei välttämättä ole tarjolla. Vankiloissa perustetaan yhdistyksiä, jotta henkilökunta voi hakea projektirahoitusta turvatakseen vankiloihin ja nuorille sitä koulutusta, jonka pitäisi olla lakisääteisesti turvattua. Lisäksi se, mitä koulutuksen nimissä nuorille tarjotaan, ei aina täytä hajanaisuudellaan ja terapeuttisilla sisällöillään koulutuksen kriteerejä (Brunila 2012). Nuoret itse toivovat koulutusta, joka johtaisi johonkin muuhunkin kuin itsetutkiskeluun ja seuraavaan lyhytkestoiseen toimenpiteeseen.

Tutkimusryhmämme kiinnostuksena onkin tehdä tutkimusta yhdessä erilaisissa tilanteissa elävien nuorten kanssa. Tavoitteenamme on laajentaa tutkimusta muihin pohjoismaihin, Britanniaan ja Australiaan. Nuorten koulutuksen ohella meitä kiinnostavat kysymykset koulutuspolitiikan ja koulutuksen käytäntöjen markkinoitumisesta, mutta myös laajemmin työelämästä ja työmarkkinajärjestelmästä (Kainulainen 2012, tulossa), tietokykykapitalismista (Paakkari, tulossa) ja kaikkialle leviävästä yrittäjämäisestä eetoksesta (Mononen 2007, Mononen-Batista Costa \& Brunila, tulossa). Rahan kieli etsii tehokkaampia tapoja puhutella meitä ja valjastaa koko persoonan peliin. Rahan kielen läpitunkevuus jaksaa edelleen silloin tällöin yllättää. Sen myötä sosiaalisista suhteistammekin on kehkeytymässä jotain, johon investoidaan, ja jota ennakoidaan, laskelmoidaan ja manageerataan. Yhä useampi kollega on alkanut käyttää termejä "peli" ja "selviytyminen" puhuessaan toiminnasta yliopistolla.

Olemme kiinnostuneita myös yhteiskunnan ja koulutusjärjestelmän terapisoitumisesta, mistä keskustellaan vilkkaasti jo Yhdysvalloissa, Kanadassa, Australiassa, Uudessa-Seelannissa sekä useissa eri Euroopan maissa mutta Suomessa edelleen vähän.
Terapisoitumisella tarkoitamme eetosta, jossa erilaisista terapiamuodoista ja populaaripsykologiasta lainatut ajatukset ja kieli alkavat muokata koulutuksen muotoja ja sisältöjä (esim. Ecclestone, Hayes \& Furedi 2005, Dahlstedt et al McLaughlin, 2011, McLeod 2012). Ilmiö ei ole uusi, mutta se on vahvistunut markkinoitumisen myötä. Terapisoitumista voi luonnehtia myöhäismodernille ajalle ominaiseksi kulttuuriseksi tilaksi, joka on vahvistunut erityisesti yksilökeskeisyyden voimistumisella ja kollektiivisen ja yhteisöllisen romahtamisella, mutta myös psykologisen tieteen aseman vahvistumisen myötä (Furedi 2004). Koulutuksen terapisoitumisessa yksi silmiinpistävimmistä vallan toiminnan muodoista on yhteiskunnallisten ongelmien kääntyminen riippuvaisina, vajavaisina, kyvyttöminä ja haavoittuvina nähtyjen yksilöiden ongelmiksi. Terapisoituminen ulottuu myös siihen, miten ruumiillisuutta on mahdollista ymmärtää ja miten kyvykäs ruumis vaikuttaa kuin itsestään herättävän myönteisiä tunteita ja ilmentävän samastuttavissa olevaa elämää (Vaahtera 2012; Vaahtera \& Vähäpassi 2014). Ruumiillisten kykyjen kehittämistä saatetaankin perustella terveyden ja turvallisuuden sijaan epämääräisemmällä, mutta yhtä normalisoivalla yksilön tarpeella (Vaahtera 2012). Samanaikaisesti ruumiillista kyvyttömyyttä pidetään itseluottamuksen puutteena tai rajoittuneisuutena (emt.). Miten siis kyvykkyysihanteista jollain tapaa poikkeavat voivat muodostaa myönteisen käsityksen itsestään, jos kyvyttömyyttä pidetään esimerkiksi itseluottamuksen puutteena?

Yksi esimerkki terapisoitumisesta on, että Suomessakin ADHD:n kaltaisia oireyhtymiä diagnosoidaan aiempaa enemmän (Teittinen 2011, Vehkakoski 2006). Lisäksi lapsia ja nuoria lääkitään yhä enemmän ADHD-diagnoosin takia. ADHD-testejä tehdään myös niissä nuoriin kohdistuvissa projekteissa, joissa olemme vierailleet. Ne kuvataan toimintaa helpottavina, mutta myös ongelmallisina. Eräässä keskustelussa nuorten kanssa työskentelevä opintoohjaaja kertoi, kuinka hänen luokseen tulee erilaisia virallisia tai hieman epävirallisempia diagnooseja aiemmissa koulutusohjelmissa saaneita nuoria, joille on määrätty lääkitys. Opinto-ohjaaja ei kuitenkaan itse huomaa nuorissa olevan mitään vikaa. Lääkityk- 
sistä on pikkuhiljaa luovuttu. Opinto-ohjaaja mainitsi kuitenkin tiedostavansa, että koulutusorganisaatiot tienaavat lisärahoitusta diagnostiikalla.

Hieman kärjistäen voi sanoa, että koulutuksesta on alkanut kehkeytyä haavoittuneita parantavaa ja eheyttävää, "oikeanlaisen" kyvykkyyden ja mielentilan valmentamista turvallisessa ilmapiirissä. Tämä näkyy varhaiskasvatuksesta aikuiskoulutukseen. Riittävän eheytymisen jälkeen koulutus lunastaa uudestaan paikkansa transnationaalin hallinnan tuottamien ja varmistamien hyvien käytäntöjen mukaisten täsmätaitojen ja kompetenssien ketteränä tarjoiluvaununa. Kapitalismin kriisin aikana terapisoituminen muodostaa kiinnostavia yhteyksiä markkinoitumiseen. Kun koko koulutusjärjestelmä on jossain mielessä pakotettu perustelemaan olemassa olonsa oikeutusta uudella entistä markkinahenkisemmällä tavalla, terapisoitumisella näyttäisi olevan paikkansa tarjoamalla potentiaalia ulottua yhä laajemmalle ihmisen elämänpiiriin ja persoonaan. Kysymmekin tutkimuksellamme, onko terapisoitumisesta tulossa tai jo tullut tehokkaampi tapa legitimoida koulutusta, ja mitä koulutuksen terapisoitumisesta on seuraamassa jos opimme toimimaan kyseisen eetoksen mukaisesti ja ehkä tuntemaan siitä myös mielihyvää?

Olemme tutkimusryhmässäni kiinnostuneita tietokapitalismin, terapisoitumisen, markkinoitumisen ja transnationaalin hallinnan (EU, OECD) ohella myös projektiyhteiskunnan ja verkostopolitiikan seurauksista. Meitä kiinnostaa lisäksi lasten, nuorten, aikuisten, opettajien ja muiden koulutuksen ja työelämän piirissä toimivien liikkumavara koulutusjärjestelmässä ja laajemmin yhteiskunnassa. Myös tasaarvopolitiikkaa ja tasa-arvotyötä koskeva tutkimus on ryhmässä vahvaa. Sen tarkastelussa huomioidaan laajempia yhteiskunnallisia ja koulutuspoliittisia valtasuhteita sekä tasa-arvon eri ulottuvuuksia yhteiskunnallisten erontekojen näkökulmista (esim. Ikävalko 2010, Ikävalko ym. 2012, Brunila \& Ylöstalo 2013). Väittelin vuonna 2009 hyvinvointipolitiikan markkinoitumisesta. Tarkastelin väitöstutkimuksessani erityisesti tasa-arvopolitiikkaa ja tasa-arvotyötä kasvatuksessa, koulutuksessa ja laajemmin työelämässä. Toin esille sitä liikkumavaraa, jota rahan kieli ja projektit yhtäältä mahdollistavat ja toisaalta säätelevät.
Jatkuvasti ajankohtainen kysymys näyttää olevan se, mitä kaikkea tasa-arvon ja sosiaalisen oikeudenmukaisuuden nimissä itse asiassa tullaankaan tehdyksi.

\section{UUDEN TUTKIMUSFOORUMIN PERUSTAMINEN}

Ajattelen, että tieto muotoutuu yhteisöllisesti. Puhun mielelläni me-muodossa, millä haluan hieman haastaa individualistista ajattelua suhteessa tietoon ja tietämiseen. Professuuri mahdollistaa uusia aloitteita. Olemme tutkimusryhmäni ja kasvatustieteen piirissä Helsingin yliopistossa toimivien kollegoiden kanssa suunnittelemassa tänä vuonna toimintansa aloittavaa kasvatuksen ja koulutuksen sosiaalisen oikeudenmukaisuuden ja tasa-arvon kysymyksiin keskittyvää tutkimusfoorumia AGORA for the Study of Social Justice and Equality. Tavoitteena on, että tutkimusfoorumista kehittyy kansallisesti ja kansainvälisesti tunnettu tutkimuskeskus, joka toimii yhteistyöareenana useille tutkimusryhmille ja -yhteisöille, opetuksen kehittämiselle, hankkeille ja aktiiviselle yhteiskunnalliselle vaikuttamiselle.

Tutkimusfoorumin lähtökohtana ovat kriittisyyden, demokraattisuuden ja kollektiivisuuden periaatteet, jotka lainaamme foorumin osana aktiivisesti toimivasta Rhizome of Critical Studies in Education of Adults -tutkimusverkostosta (ks. rhizomehelsinki.blogspot.fi). Periaatteisiin kuuluu myös, että jokaisella tutkimusfoorumissa toimivalla on liikkumavaraa vahvistaa sitä, mitä on jo tehty, mutta myös lähteä tekemään uusia avauksia. Lisäksi lähestymistavat ovat moniäänisiä ja monitieteisiä. Haluamme, että tehty työ tulee näkyväksi ja että jokaisella foorumissa toimivalla on kokemus kuulluksi tulemisesta.

Uusien avauksien ohella vahvistetaan ja laajennetaan tutkimusverkostojen ja tutkimusyhteisöjen jo olemassa olevaa osaamista. Näistä tärkeimpänä voisi mainita Pohjoismaisen Huippuyksikön Justice through Education in the Nordic Countries, jota olen itsekin mukana johtamassa (ks. blogs.helsinki.fi/just-ed). Vaikka huippu-ajattelusta voi olla montaa mieltä, huippuyksikkö-rahoituksen saaminen seuraavaksi viideksi vuodeksi turvasi yhteiskuntatieteellisen kasvatustieteen ja oikeudenmukaisuuden ja tasa-arvon tutkimuksen tulevaisuuden Helsingissä. Vallan tutkijana kannatan ajatusta siitä, että opimme hyö- 
dyntämään järjestelmiä, jotka meitä hyödyntävät ja samaan aikaan tunnistamme kyseisiä valtasuhteita ja raivaamme niihin liikkumavaraa (esim. Brunila 2009). AGORA-tutkimusfoorumi toimii samalla Huippuyksikön Helsingin alueellisena keskuksena. Lähitulevaisuudessa järjestämme tilaisuuksia esimerkiksi yhteiskunnallisesta vaikuttamisesta, vammaistutkimuksesta, kriittisen ajattelun kehittämisestä opetuksessa ja tutkimuksesta ja kielipolitiikasta kouluissa. Tutkimusfoorumissa toimii jo nyt Kasvatus, yhteiskunta ja kulttuuri-tutkimusseminaari, jossa kokoontuu yhteiskuntatieteellisen kasvatustieteen nuoria ja vanhempia tutkijoita. Luemme ja keskustelemme yhdessä ajankohtaisista artikkeleista ja kirjoista, järjestämme lukupiirejä ja suunnittelemme uusia yhteiskirjoittamisen muotoja.

AGORA-tutkimusfoorumin keskeisinä alueina ovat ainakin koulutuspolitiikan, koulutuksen kulttuurien ja käytäntöjen ja laajemmin työelämän tarkastelu eriarvoisuuden ja oikeudenmukaisuuden näkökulmista ja toimijuuden, vallan ja yhteiskunnallisten erontekojen (kuten esim. iän, sukupuolen, kulttuurisen taustan, vammaisuuden jne.) huomioiminen suhteessa näihin. Foorumin vahvuus on laajaalaisessa yhteiskuntatieteellisessä lähestymistavassa jossa analysoidaan esimerkiksi koulutuksen markkinoitumista, tietokapitalismia, teknologisoitumista, individualisaatiota ja yrittäjämäistä eetosta sekä lasten, nuorten, aikuisten, opettajien, opiskelijoiden, ohjaajien, työelämän kehittäjien ja muiden asiantuntijoiden ja työntekijöiden toimintaa ja liikkumavaraa näistä näkökulmista käsin. Foorumin tutkimus ulottaa eriarvoisuuteen liittyvät kysymykset varhaiskasvatuksesta peruskoulutukseen, lukioon, korkeakoulutukseen, aikuiskoulutukseen ja työelämään.

Vaikka teoretisoinneista ja uusien käsitteiden kokeilemisesta on helppo innostua, näen että tutkijoilla on myös laajempi vastuu siitä, mitä olemme tekemässä. En ole henkilökohtaisesti kiinnostunut kehittelemään teorioita pelkästään niiden itsensä takia. Teorioiden ja tutkimusten tulisi auttaa ymmärtämään ongelmia, joita yhteiskunnassamme ja mahdollisesti myös omassa ajattelussamme on, mutta myös tarjoamaan ymmärrystä ajatella ja toimia toisin. Nykyisin yliopistolla tutkijat pidetään kiireisinä takomassa liukuhihnalla jopa kymmenistä tutkijoista muodostuvissa letkoissa korkeimman A1-tason artikkeleita. Niitä tarjotaan sitten rankkauksessa riittävän korkealla luokiteltuun journaaliin. Yliopisto on hankalassa tilanteessa, koska senkin täytyy todistella rahan kielellä olemassa olonsa oikeutusta. Mutta en malta olla tässä lainaamatta kollegaani Vanessa de Oliveira Andreottia, joka sanoi:

"Kristiina, it might be that we are the last generation that is able to change something in the Academia. But if it looks like we are going down, let's make sure we go down shooting".

Näen, että pieni idealistisuus, jota onneksi vielä on, ei taida olla uuden kehittelyssä pahitteeksi. Yliopistollakin on havaittavissa tiukempaa oman edun valvontaa ja kyynistymistä. Kaikenlainen uuden kehittely ei välttämättä saa ihmisiä heti innostumaan. Ensimmäisenä voi tulla ajatelleeksi, että onko tämä uusi kehittely kenties minulta jotain pois tai uhkaako se asemaani jollain tavalla. Uskon kuitenkin, että kun toiminnasta saadaan riittävän kiinnostavaa, se houkuttelee ihmisiä mukaan. Esitänkin lopuksi avoimen kutsun kaikille näistä teemoista ja asioista kiinnostuneille olemaan yhteydessä.

\section{Kristiina Brunila}

FT, kasvatuksen ja koulutuksen tasa-arvon ja oikeudenmukaisuuden tenure track -professori Helsingin yliopisto

\section{LÄHTEET.}

Brunila, K., Hakala, K., Lahelma, E. \& Teittinen, A. (toim.) 2013. Ammatillinen koulutus ja yhteiskunnalliset eronteot. Helsinki: Gaudeamus.

Brunila, K. \& Ylöstalo, H. (2013). E-pub ahead of print. Challenging Inequalities in Education and in Working Life. A Mission Possible? Journal of Education \& Work.

Brunila, K. \& Isopahkala-Bouret, U. (toim.) painossa. Marginaalin voima. Aikuiskasvatuksen 51. vuosikirja. Aikuiskasvatuksen tutkimusseura ja Kansanvalistusseura.

Brunila, K. (2012). A DIMINISHED SELF. Entrepreneurial and Therapeutic Ethos working with the Same Aim. European Educational Research Journal 11(4), 477-486. 
Dahlstedt, M., A. Fejes and E. Schonning. 2011. The will to (de)liberate: shaping governable citizens through cognitive behavioural programmes in school, Journal of Education Policy, 26(3), 399-414.

de Oliveira Andreotti, V. \& Pashby, K. (2013). Digital Democracy and Global Citizenship Education: Mutually Compatible or Mutually Complicit. The Educational Forum, 77(4), 422- 437.

Ecclestone, Kathryn \& Hayes, Dennis \& Furedi, Frank (2005). Knowing me, knowing you: The rise of therapeutic professionalism in the education of adults. Studies in the Education of Adults 37(2), 182-200.

Furedi, F. (2004). Therapy culture: Cultivating vulnerability in an uncertain age. London: Routledge.

Ikävalko, E. (2010). Suunnittelu on tekoja: Tasaarvosuunnittelu osana koulujen tasa-arvotyötä. Teoksessa Suortamo, M., Tainio, L., Ikävalko, E., Palmu, T. \& Tani, S. (toim.) Sukupuoli ja tasa-arvo koulussa, 145-158.

Ikävalko, E. (2010). Taistelu tiedosta: Tasa-arvolain uudistus vuosituhannen vaihteessa. Naistutkimus, 23(4), 58-61.

Ikävalko, E. \& Brunila, K. (2011). Tasa-arvosuunnittelu managerialisten hallinnan tekniikkana. Sosiologia, 48(4), 323-337.

Kainulainen, V. (2013). Työssä käyvät köyhät. Katsaus aiheeseen tutkimuskirjallisuuden valossa. Palvelualojen ammattiliitto PAM. http://www.pam. fi/fi/medialle/Documents/Tyossakauvat_koyhat_ pam2013.pdf

Kainulainen, V. ( 2010). Yhdessä meillä se voima on. Etnografinen tutkimus Palvelualojen ammattiliiton luottamusmies- ja työsuojelukoulutuksista. Pro gradu -työ. Helsingin yliopisto.

Justice through Education Pohjoismainen Huippuyksikkö: http://blogs.helsinki.fi/just-ed/

Kurki, T. \& Brunila, K. (tulossa). The Wheel of (Mis) fortune. Education and training as projectised and precarious politics. Power \& Education.

Lehtonen, J. (toim). 2011) Sukupuolinäkökulmia tutkimusperusteiseen opettajankoulutukseen. TASUKO-hankkeen loppujulkaisu. Helsinki: Helsingin yliopisto.

Malin, A., Sulkunen, S. \& Laine, K. (2012). PIAAC 2012. Kansainvälisen aikuistutkimuksen ensituloksia. Opetus- ja kulttuuriministeriön julkaisuja 2013:19.

McLaughlin, K. 2011. Surviving Identity: Vulnerability and the Psychology of Recognition. London: Routledge.

McLeod, Julie. 2012. Vulnerability and the neo-liberal youth citizen: a view from Australia, Comparative Education, 48(1), 11-26.

Mertanen, K. (2013). Vankilakoulutus marginalisaation hallintana. Diskurssianalyyttinen tutkimus naisille vankilassa järjestettävästä koulutuksesta. Pro gradu -työ. Helsingin yliopisto.
Mononen-Batista Costa, S. (2007). Yrittäjäksi jos yltäisin, oman onneni seppä jos oisin! Keskustelua yksilön vastuullistamisesta. Nuorisotutkimus 25(1), 19-31.

Mononen-Batista Costa, S. \& Brunila, K. (arvioitavana). The Education of Young People 'At Risk' in an era of Entrepreneurial Education.

Niemi, A-M. \& Kurki, T. (2013). Amislaiseksi valmistettu, valmennettu, kuntoutettu ja ohjattu? Teoksessa Kristiina Brunila, Katariina Hakala, Elina Lahelma \& Antti Teittinen (toim.). Ammatillinen koulutus ja yhteiskunnalliset eronteot. Helsinki: Gaudeamus.

Paakkari, A. (tulossa). Koulu ja koneet. Tietokykykapitalismi luokkahuoneessa. Teoksessa Kristiina Brunila, Jussi Onnismaa ja Heikki Pasanen. Tietokykykapitalismi. Aikuiskasvatuksen 52. vuosikirja. Aikuiskasvatuksen tutkimusseura ja Kansanvalistusseura.

Rhizome of Critical Studies in Education of Adults: http://rhizomehelsinki.blogspot.fi/

Teittinen, A. (2011). Onko diagnoosi tarpeellinen? Pohdintoja lääketieteellisten diagnoosien yhteiskunnallisista merkityksistä. Teoksessa Suvi Vaarla (toim.): Alkoholin vaurioittamat. FASD-lasten ja -nuorten mahdollisuudet hyvään elämään. Helsinki: Kehitysvammaliitto.

Vainio, K. (2012). Tervetuloa hallittavaksi! Tohtorikoulutuksen hallinta ja tohtorikoulutettavan neuvotteleva toimijuus. Pro gradu -työ. Helsingin yliopisto.

Vaahtera, E. (2012). Compulsory Able-Bodiedness and the Stigmatised forms of Nondisability. Lambda Nordica, 17(1-2), 77-101.

Vaahtera, E. \& Vähäpassi, E (2014) (painossa) Vammaisuuden haluaminen ja kulttuuriset normit. Teoksessa Meskus Mianna, Irni Sari, Oikkonen Venla (toim.) Muokattu elämä: Teknotiede, sukupuoli ja materiaalisuus. Tampere: Vastapaino.

Vehkakoski T. Ominaisuuksista oireyhtymiksi. Neuropsykiatriset diagnoosit ja neurotieteelliset selitysmallit vammaisuuden tuottajina. Teoksessa Teittinen A. (toim.) Vammaisuuden tutkimus. Yliopistopaino, Helsinki 2006.

\section{VIITTEET}

1 Helsingin yliopisto on ottanut käyttöönsä opetus- ja tutkimushenkilöstön vakinaistamispolun (tenure track), jonka tavoitteena on lisätä akateemisen uran ennustettavuutta, kilpailukykyä ja houkuttelevuutta sekä edistää yliopiston kansainvälistymistä. Yliopisto palkkaa lahjakkaita ja motivoituneita henkilöitä, jotka ovat suorittaneet tohtorin tutkinnon enintään 10 vuotta sitten ja tämän jälkeen hankkineet tieteellisiä ja muita alalla tarvittavia ansioita. Henkilöt palkataan apulaisprofessoriksi työsopimussuhteeseen, jonka aikana pätevöidytään niin että henkilöt voidaan palkata vakinaisiin professuureihin. 